\title{
Shades and Nuances
}

Austen's intricate elegancies sometimes cause serious problems. Whereas some of our Norwegian translators demonstrate a good and even admirable grasp of Austen's language, others struggle. The Hauges particularly have difficulties dealing with complicated syntactical structures, and their tactics seem to be to pick out a significant word and invent a new sentence based on this. There are four illustrative examples in the chapter containing Darcy's first proposal in Pride and Prejudice (II, 11).

To start with, Mr Darcy talks of "the family obstacles which judgment had always opposed to inclination" (189), meaning that his reason tells him to set social pride against love. In the Hauges' rewriting, this is turned into a general lesson on reason versus emotions: "He pointed to the sensible in preserving a sane judgment when the emotions took unwanted directions". As if to underline this perceived preaching in Darcy, they skip the following two lines, and instead end the sentence with "etc., etc.". ${ }^{1}$ Here the translators literally give in and demonstrate that they are defeated by Austen's long sentences. However, in so doing, they create the impression that Darcy is tiresome and long-winded, which is not at all the case in this very intense scene.

The second example is perhaps less serious, but still stylistically weak. Elizabeth accuses Darcy of treating Wickham unfairly, ending with a rhetorical question of how he can defend himself, clearly not expecting him to be able to do so: "or under what misrepresentation, can you here impose upon others?" (191). When this is translated: "Or how would you present the case?" it is an open and polite request that invites an explanation. ${ }^{2}$ Which naturally does not come, since Darcy reacts to the emotional accusation of the original.

The third example in this chapter turns Austen's meaning upside down. When Darcy thinks that his mistake has been to be honest about his scruples, he says that he should have "with greater policy concealed my struggles, and flattered you into the belief of my being impelled by unqualified, unalloyed inclination; by reason, by reflection, by every thing" (192). The Hauges have caught the "struggle" and the "reason", but changed the sentence into: "concealed my struggle with myself and only ensured you that you were the object

1 "Han påpekte det fornuftige i å bevare sunn dømmekraft når følelsene gikk i uønsket retning"; "osv., osv." (Austen, Stolthet og fordom, c. 1972, 153). See also Chapter 3 above.

2 “Eller hvordan vil De fremstille saken?" (ibid., 155).

(C) MARIE NEDREGOTTEN SøRBø, 2018 | DOI 10.1163/9789004337176_007

This is an open access chapter distributed under the terms of the prevailing C.C-BY-NC License. 
of a love that had nothing to do with reason and reflection!" 3 This is the opposite of Darcy's meaning: he means to say that he should have convinced her that his love is supported by his reason, but in this 1972 Norwegian version, he says that he should have claimed that his love has nothing to do with reason.

In the last example in this chapter, the translators have recognized the word "pardon" and made up a new sentence based on this. In Elizabeth's reflections on Darcy after he has gone, she thinks of "his unpardonable assurance in acknowledging, though he could not justify it" (that is his part in Jane's story) (193). This is rendered "and that he did not even want to apologize!"4 Clearly, the distinction between "unpardonable" and "unapologetic" is too fine for these translators.

Other translators also struggle with these scenes, for instance Lalli Knutsen. When Elizabeth, deeply troubled by Darcy's letter, tries to find out the truth about Wickham, she searches for good qualities in him, which would "atone for those casual errors, under which she would endeavour to class, what Mr Darcy had described as the idleness and vice of many years continuance" (206). In reading this contrast between Elizabeth's wish to diminish Wickham's faults, and Darcy's harsh truth about him, the emphasis should be on "she" and "Mr Darcy". When this is not understood, Knutsen, for instance, translates "atone for casual errors of the kind that could belong under what Darcy had described as many years of living in idleness and vice". ${ }^{5}$ This does not make sense - the juxtaposition of opposites is lost and evened out. Casual error has been made equivalent to years of vice. The Hauges have problems with the same sentence. Their slightly better version reads "or other more minor errors that could explain what Mr Darcy called his idleness and vice". ${ }^{6}$ Even Alfsen makes the same mistake, and follows Knutsen, with just a slight variation of the wording. ${ }^{7}$ Harbitz, however, has understood, although simplifying, the sentence: "or at least cast a conciliatory light over his weaknesses - as she named them to herself". 8

3 "fortiet min kamp med meg selv og bare forsikret Dem om at De var gjenstand for en kjærlighet som ikke hadde noe med fornuft og ettertanke å gjøre!” (ibid., 156).

4 "og at han ikke en gang hadde lyst til å be om unnskyldning!" (ibid., 157).

5 "oppveie tilfeldige feiltrinn, slike som kunne høre inn under det som Darcy hadde beskrevet som mange års liv i lettsindighet og last" (Austen, Stolthet og fordom, 1947, 180).

6 "eller andre mer bagatellmessige feiltrinn som kunne forklare det Mr Darcy kalte hans dovenskap og lastefullhet" (Austen, Stolthet og fordom, c. 1972, 167).

7 "veie opp for visse flyktige feiltrinn som kunne høre inn under det Mr. Darcy hadde beskrevet som mange års liv i last og lediggang” (Austen, Stolthet og fordom, 2003, 196).

8 "eller i det minste kaste et forsonende skjær over hans svakheter - som hun kalte dem for seg selv" (Austen, Elizabeth og hennes søstre, 1930, 146-47). 
In the rather complex paragraph about Elizabeth's "retrospective glance" over her own shifting feelings for Darcy she "sighed at the perverseness of those feelings which would now have promoted its [i.e. their acquaintance] continuance, and would formerly have rejoiced in its termination" (279). Here Knutsen seems to give in, and renders it "sighed that she had let her feelings be led astray". ${ }^{9}$ The Hauges also have problems with the syntactical structure, although they have caught the main meaning: "The thought of possibly not seeing him again and that would previously have pleased her, now caused deep sorrow". 10

It is misleading to say that Wickham asked Darcy for "a temporary economic support" as in the Hauges' translation of "immediate pecuniary advantage" (200). ${ }^{11}$ The whole point is that he immediately got a full and final compensation for the living he did not want. Alfsen's choice is excellent, employing words exactly corresponding to the English original, including the quasi-Latin adjective. $^{12}$

The Hauges furthermore misunderstand the sentence "in farther justification of Mr Darcy, she could not but allow that Mr Bingley, when questioned by Jane, had long ago asserted his blamelessness in the affair" (207). The affair Elizabeth is thinking of is the one between Darcy and Wickham, but the translators think it is the relationship between Jane and Bingley: "And concerning Darcy, she had to allow that he perhaps by his own conviction was not so much to be blamed in the affair between Jane and Mr Bingley". ${ }^{3}$

Meryton gossip has it that Wickham was in debt to every tradesman, and "his intrigues, all honoured with the title of seduction, had been extended into every tradesman's family" (294). The Norwegian translators have varying grasp of the implications of "seduction". The Hauges make a somewhat confused attempt at rendering the sentence in "he had employed all different 'arts of

9 "sukket over at hun hadde latt sine følelser ledes på villspor" (Austen, Stolthet og fordom, 1947, 239).

10 "Tanken om mulig ikke å se ham mer $[$ sic $]$ og som tidligere ville ha gledet henne, vakte nå dyp sorg" (Austen, Stolthet og fordom, c. 1972, 219).

11 "foreløbig økonomisk støtte" (ibid., 162).

12 "umiddelbar pekuniær begunstigelse" (Austen, Stolthet og fordom, 2003, 191). The two cited Norwegian versions also serve as examples of the different styles attempted by the translators, which is the topic of a later chapter.

13 "Og hva Darcy angikk, måtte hun innrømme at han kanskje ut fra sin overbevisning, ikke var så meget å dadle i saken mellom Jane og Mr Bingley” (Austen, Stolthet og fordom, c. 1972, 168). 
seduction' towards the creditors and their families". ${ }^{14}$ While Harbitz has a good solution: "He owed money to every tradesman in the place, it was said, and in every tradesman's family he had acted the seducer". ${ }^{15}$ The translator of the 1974 serial, or conceivably its editor Lise Jor, opted to omit this sentence from an otherwise well translated passage. It is perhaps a little too harsh for the readers of Familien ("the family").

Other examples of translator's challenges may be more banal. Rather than Mr Bennet's declaration that "Into one house in this neighbourhood, they shall never have admittance" (310), the Wickhams are banned from all houses in the Hauges' version: "They shall not live in a single house in the area! And they will not be admitted to a single home". ${ }^{16} \mathrm{Mr}$ Bennet's immediate explanation: "I will not encourage the impudence of either, by receiving them at Longbourn", is also misunderstood: "I will not insult my neighbours by receiving them here at Longbourn".

Among these less serious deviations from the source text is Alfsen's interpretation of Darcy's "savage", when he observes to Sir Lucas that "Every savage can dance" (25). ${ }^{17}$ The obvious anthropological meaning has here become a sociological comment. Alfsen translates "the less polished societies of the world" as "less cultivated parties", where everybody can dance, however primitive (uncultured) they are. The earlier translations have kept the correct meaning.

\section{Nuances Lost, Influencing Our Image of the Characters}

Mistakes of translation may inadvertently change the implications of a speech or the impact of a character and event. Austen's effect may often rely on nuances and details that seem insignificant, but carry a peculiar weight. Lydia, for instance, "endeavoured to amuse" her sisters with her chatter (222) but the phrase indicates that she did not entirely succeed. However, in the Hauges' translation she succeeds: "Lydia managed to entertain them all". ${ }^{8}$ "Poor Lydia!"

\footnotetext{
14 "han hadde benyttet alle slags 'forførelseskunster' overfor kreditorene og deres familier" (ibid., 231).

15 "Han skyldte penger til hver kjøbmann på stedet, blev det sagt, og i hver kjøbmanns familie hadde han opptrådt som forfører" (Austen, Elizabeth og hennes søstre 1930, 190).

16 "De to skal ikke bo i et eneste hus her på egnen! Og de vil heller ikke bli invitert i et eneste hjem."; “Jeg vil ikke fornærme mine naboer ved å motta dem her på Longbourn” (Austen, Stolthet og fordom, c. 1972, 244).

17 "populær i de mindre dannede selskaper. Selv den mest primitive kan danse" (Austen, Stolthet og fordom, 2003, 28).

18 "klarte Lydia å underholde dem alle" (Austen, Stolthet og fordom, c. 1972, 179).
} 
is also a rather poor translation of "Thoughtless, thoughtless Lydia!" (292). ${ }^{19}$ The first denotes pity, the second criticism and blame. The family has just read her utterly superficial elopement letter, leaving them distraught while she herself treats it as a joke.

Georgiana is said to have nourished a "terror" for her brother, while in reality she only felt "respect" $(388) \cdot{ }^{20}$ Foolhardiness or rashness is certainly not a fitting description of Mr Collins, but still the chosen translation of "the consequential feelings" resulting from his good fortune in life $(70) \cdot{ }^{21}$ So far from being a daredevil, the phrase implies that he felt himself to be an important person. In another instance, it seems strange to let Mr Collins inform Lady Catherine of Mr Darcy's intentions to marry. ${ }^{22} \mathrm{Mr}$ Collins has no connection with $\mathrm{Mr}$ Darcy. In the novel, there are only rumours of the marriage, reported to Collins by the Lucases.

Mrs Bennet is "not so well pleased" (313) with the Wickhams being sent North, and it seems altogether a phrase more fitting her general mood, than the translation "very unhappy".23 While Kitty's peevish absurdity, an echo of her mother, is straightened out by shuffling and redistributing the original word order:

'I cannot see why Mrs Forster should not ask $m e$ as well as Lydia', said she, 'though I am not her particular friend. I have just as much right to be asked as she has, and more too, for I am two years older'. (230)

'I cannot understand why Mrs Forster could not just as well have invited me as Lydia?' she said. 'She should rather have invited me because I am two years older. But then, I am not her special friend!'24

Here, in translation, it sounds as though Kitty finds the answer to her own question, while in the original novel, she does not see that this is indeed the answer, and remains absurd.

\footnotetext{
19 "Stakkars Lydia!" (Austen, Stolthet og fordom, 1947, 250).

$20 \quad$ "en skrekk" (Austen, Stolthet og fordom, c. 1972, 310).

21 "dumdristighet" (Austen, Stolthet og fordom, 1947, 69).

22 “at han akter ..." (Austen, Stolthet og fordom, 2003, 334).

23 "meget ulykkelig" (Austen, Stolthet og fordom, c. 1972, 246).

24 "Jeg begriper ikke hvorfor Mrs. Forster ikke like godt kunne ha invitert meg som Lydia?" sa hun. "Hun skulle heller ha bedt meg for jeg er to år eldre. Men så er jeg jo heller ikke hennes spesielle venn!" (ibid., 186).
} 
To say that Mr Bennet "had no other choice" than to agree to the terms for Lydia's marriage outlined by Mr Gardiner, gives the wrong impression. ${ }^{25}$ Austen's "could have no hesitation" means that it was so advantageous for him that he must jump at it (308). Mr Bennet clearly is seen to be very relieved that he has to sacrifice so little.

In another significant modification, Mr Bingley is said to "have good chances of really being as happy as he now hoped", "in spite of being newly engaged". 26 This makes us wonder why his engagement would reduce his chances of happiness. What Austen says is "in spite of his being a lover, Elizabeth really believed all his expectations of felicity, to be rationally founded" (347). One of the author's many ironies on love and lovers, it indicates that although people in love are too optimistic and blind to the dangers, in this case there is reason to hope.

Even Elizabeth's moral character may be altered by translators. In one version, she no longer cares what happens once she has warned her father against sending Lydia to Brighton: "She knew at any rate that she had done her duty, come what may". ${ }^{27}$ This self-righteousness is not what we see in Austen, where Elizabeth merely tries to master her disappointment: "She was confident of having performed her duty, and to fret over unavoidable evils, or augment them by anxiety, was no part of her disposition" (232).

Translators may perhaps inadvertently reduce Elizabeth's attempts to take some measure of control in the last proposal scene. Harbitz cuts her active decision to remain behind with Mr Darcy rather than accompany Kitty. Knutsen cuts the word "boldly" when she opts for walking alone with Darcy. She also deletes her "forming a desperate resolution". ${ }^{28}$ Harbitz keeps "boldly" but translates it as "bravely", which is more defensive and less proactive.

Elizabeth, indeed, becomes more uncertain when the Hauges transfer Darcy's anxieties to her. "Elizabeth feeling all the more than common awkwardness and anxiety of his situation" (366) is translated as if the last three words were not there: "Elizabeth felt even more uncertain". ${ }^{29}$ They also question her emotional stability. Elizabeth comments, with self-ironic understatement, that her "opinions" are not "entirely unalterable" (368), referring to her changed

\footnotetext{
25 "hadde ikke noe annet valg" (Austen, Stolthet og fordom, 2003, 284).

26 "Og selv om han var nyforlovet, mente Elizabeth at han hadde gode chanser til virkelig å bli så lykkelig som han nå håpet” (Austen, Stolthet og fordom, c. 1972, 275).

27 "Hun visste i hvert fall at hun hadde gjort sin plikt, så fikk det siden gå som det ville" (Austen, Stolthet og fordom, 1947, 202).

28 Austen, Elizabeth og hennes søstre 1930, 236; Austen, Stolthet og fordom, 1947, 315.

29 "Elizabeth følte seg enda mer usikker" (Austen, Stolthet og fordom, c. 1972, 292).
} 
attitude to Darcy. The translation "my feelings are a little unstable" simply gives the wrong impression. ${ }^{30}$

In Knutsen's version, Elizabeth "almost hopes" that Bingley will receive a letter from Darcy, excusing himself from not being able to come. This is rather absurd, as it is her worst fear, which she tries to prepare herself against and therefore "half expected". 31

Jane's character is one of unfailing kindness and mildness. When Elizabeth asks Jane whether she blames her for having defended Wickham before, Jane answers "No - I do not know that you were wrong in saying what you did" (224). Jane, true to her character, carefully refrains from blaming Elizabeth, although she does not share her harsh views of other people. Translators tend to modify her answer. Harbitz translates, "No. What you said was, after all, correct". This is a very different attitude, supporting Elizabeth's condemnation of Mr Darcy, which Jane never does. ${ }^{32}$ Nor does Knutsen grasp the nuances of Jane's answer, and translates it: "No, I do not think it was wrong of you to say what you said about him". ${ }^{33}$ The Hauges make the same mistake: "No, I know that you did nothing wrong in speaking as you did". ${ }^{34}$ Only Alfsen translates Austen's meaning "I do not know that you were wrong". 35

Mr Darcy does not want to "join in the censure of" Elizabeth, but the Hauges say that he does not want to "comment on" her (46). ${ }^{36}$ In Norwegian, Darcy refuses to talk of Elizabeth; in English, he refuses to criticize her. His "charming long letters" (48), in Miss Bingley's phrase, are mostly well translated as "enchanting", while Alfsen's choice, "fine" and the 1974 choice "nice" are tamer and lose some of the humour of Darcy's laconic attitude to the praise. ${ }^{37}$

Mrs Gardiner would not be so forward as to suggest that "a low phaeton, with a nice little pair of ponies" should be bought for her when Elizabeth is settled at Pemberley: she means that Elizabeth should have them for her own use. Yet translators render "would be the very thing" as "would be just the thing

\footnotetext{
$30 \quad$ "mine følelser er litt ubestandige" (ibid., 294).

31 "hadde nesten håpet" (Austen, Stolthet og fordom, 1947, 315).

32 "Nei. Det var da riktig det du sa" (Austen, Elizabeth og hennes søstre 1930, 155).

33 "Nei, jeg syns ikke det var galt av deg å si det om ham som du sa" (Austen, Stolthet og fordom, 1947, 195).

34 "Nei, jeg vet at du ikke gjorde noe galt i å snakke slik som du gjorde" (Austen, Stolthet og fordom, c. 1972, 181).

35 "Nei - jeg vet ikke om det var galt å si det du sa" (Austen, Stolthet og fordom, 2003, 212).

36 "kommentere Elizabeth" (Austen, Stolthet og fordom, cirka 1972, 45).

37 "fine, lange brev" (Austen, Stolthet og fordom, 2003, 49); "så lange og hyggelige brev" (Austen, Omvei til lykken, 1974, Part 2, 68); "bedårende" (Austen, Elizabeth og hennes søstre 1930, 39; Austen, Stolthet og fordom, 1947, 50; Austen, Stolthet og fordom, c. 1972, 46).
} 
for me"38 or "would suit me down to the ground". ${ }^{39}$ This time only the Hauges translate the original meaning. ${ }^{40}$

Whether main or minor characters, Austen's choice of phrase when describing them is highly significant, and demands a good ear. Hardly a phrase of the novels seems carelessly employed. It is a consequence of the years of writing, rewriting and editing that went into their creation. In contrast, most translators probably have to labour under much stricter time limits, and therefore make fewer efforts to polish and prune their texts. ${ }^{41}$ This should be all the more reason to give close consideration to the wording of the original work when translating.

\section{Disagreements about Austen's Meaning}

Sometimes there are more or less well-founded difficulties in determining the meaning of a passage, and translators choose different solutions. Is Mrs Bennet stirring the fire literally or metaphorically while Mr Collins seemingly falls in love with Elizabeth? "Mr Collins had only to change from Jane to Elizabeth -and it was soon done - done while Mrs Bennet was stirring the fire" (71). Alfsen sees a literal meaning. ${ }^{42}$ Three other translations have interpreted it as a metaphor. Knutsen has "it was done while Mrs Bennet added fuel to the fire" (the fuel being specified as oil in the Norwegian idiom, it cannot be taken literally). ${ }^{43}$ The Hauges have discarded the fire altogether and say plainly that he was: "strongly encouraged by Mrs Bennet". 44 Harbitz and the 1974 translation present very

38 "ville være akkurat noe for meg" (Austen, Stolthet og fordom, 2003, 299; Austen, Stolthet og fordom, 1947, 280).

39 "vilde passe mig utmerket" (Austen, Elizabeth og hennes søstre, 1930, 210).

40 "vil være tingen!" (Austen, Stolthet og fordom, c. 1972, 256).

41 Lalli Knutsen's daughter, Mette Newth, indicates as much in a newspaper interview about her parents, where she says that many of the translations were necessarily superficially executed, since they did it for the income ("Mange av oversettelsene ... måtte bli venstrehåndsarbeid. Det handlet jo ofte om å skrive for å overleve”, Arne Dvergsdal, “Knutsen Kriminal As" in Dagbladet, 2000, 17 April.

"Det var fort gjort; det var gjort mens mrs. Bennet raket opp i ilden" (Austen, Stolthet og fordom, 2003, 72).

43 "det var ganske snart gjort, mens fru Bennet hadde olje på ilden" (Austen, Stolthet og fordom, 1947, 70).

44 "Mr Collins skiftet så sin oppmerksomhet fra Jane til Elizabeth, sterkt oppmuntret av Mrs Bennet" (Austen, Stolthet og fordom, c. 1972, 64). 
similar renderings, but while the latter is metaphorical, Harbitz's could be read either way: "while Mrs Bennet blew on the fire".45

There is another example connected with Mr Collins, namely the description of his undistinguished academic career: "though he belonged to one of the universities, he had merely kept the necessary terms, without forming at it any useful acquaintance" (70). What does it mean to keep the terms? Harbitz simplifies rather too much and skips the problem: "and later at the university he had not formed any stimulating acquaintance". ${ }^{46}$ Knutsen has a similar solution, ${ }^{47}$ while the Hauges have chosen: "He had studied, but only followed the lectures and not got to know anybody". ${ }^{8}$ In a context that describes the reasons for Mr Collins' stupidity, it is a remarkable interpretation. Since he only went to lectures, he is "not a sensible man". The 1974 version deletes this passage, and only the newest translation comprises the entire sentence: "and although he had studied at one of the universities, he had only been there the necessary terms, without securing any useful acquaintances". ${ }^{49}$

A prosaic example is whether "review" should be read as a show, or as a reassessment. Mr Bennet threatens to keep Kitty from all pleasures for ten years, and then, if she is a good girl, "I will take you to a review at the end of them" (300). The two earliest translators choose the show, and two of the later choose the reassessment..$^{50}$ Jane Austen, however, may well have enjoyed the ambiguity of the pun.

What is "this explanation" that Elizabeth is referring to in her rejection of Mr Darcy's proposal (190)? She indicates that his scruples about her will undoubtedly help him overcome his love for her "after this explanation". It could either be Darcy's explanation of his scruples, of which she now reminds him,

45 "og det var snart gjort, mens fru Bennet blåste på ilden" (Austen, Elizabeth og hennes søstre, 1930, 56-57); "og fru Bennet pustet til ilden” (Austen, Omvei til lykken, 1974, Part 3).

46 "og siden ved universitetet var han ikke kommet i noget stimulerende selskap" (Austen, Elizabeth og hennes søstre 1930, 56).

47 "og skjønt han hadde ligget ved Universitetet, hadde han ikke knyttet de riktige bekjentskaper der" (Austen, Stolthet og fordom, 1947, 69).

48 "Han hadde studert, men bare fulgt forelesningene og ikke blitt kjent med andre" (Austen, Stolthet og fordom, c. 1972, 63).

49 "og skjønt han hadde studert ved et av universitetene, hadde han bare oppholdt seg der de foreskrevne terminer, uten å skaffe seg nyttige bekjentskaper" (Austen, Stolthet og fordom, 2003, 71).

50 "skal vi gå og se på en revy" (Austen, Elizabeth og hennes søstre 1930, 193); "skal jeg kanskje ta deg med på en tropperevy" (Austen, Stolthet og fordom, 1947, 258); "skal jeg ta beslutningen opp til vurdering igjen" (Austen, Stolthet og fordom, c. 1972, 236); "skal jeg tenke på saken" (Austen, Stolthet og fordom, 2003, 276). 
or it could be her own answer to him. The fact that Darcy's speech is the one that most resembles an explanation favours the first. While the second is more logical - now that you have heard my answer, you can forget me. Again, the translators are divided. Harbitz says "after my answer" and similarly, Alfsen has "when I now have said this". ${ }^{1}$ Knutsen has the opposite view: "since you now have given me this explanation"; and the 1974 translator has a similar reading: "But now that you have explained". The Hauges have evaded the problem by letting her simply say "from now on".52

In the last report of the Wickham marriage, Lydia is said to love him a little longer than he loves her, "and in spite of her youth and manners, she retained all the claims to reputation which her marriage had given her" (387). The sentence seems a riddle for the reader to enjoy. It can be read ironically, as Lydia's way of marrying had earned her a bad reputation; or seriously, as Lydia's marriage had saved her reputation. Alfsen chooses the last: "she did not shame the dignity that marriage had given her" ${ }^{53}$ If taken at face value, seriousness and dignity suit neither Lydia nor Austen's general tone. The Hauges have chosen the first: "she would always keep up the bad reputation she had gained in connection with entering marriage". ${ }^{44}$ Knutsen completely rewrites it, to the effect that her feelings "were nothing to boast of", and Harbitz as well as the 1974 translator have omitted it. ${ }^{55}$ There is, however, no reason why a translator should try and smooth out the ambiguities of a literary work, or choose between possible meanings of puns and riddles. They form an integral part of literary art, and should do so also in translation.

\section{Important Points Undermined}

Austen's complexities and ambiguities present translators with a demanding task, but even her major themes and concepts may suffer. A main interest of Pride and Prejudice is the condition of women, even through its most peculiar

\footnotetext{
$5^{1}$ "efter mitt svar" (Austen, Elizabeth og hennes søstre, 1930, 138); "når jeg nå har sagt dette" (Austen, Stolthet og fordom, 2003, 182).

52 "siden De nå har gitt meg denne forklaringen" (Austen, Stolthet og fordom, 1947, 167); "Men når De nå har forklart' (Austen, Omvei til lykken, 1974, Part 7); "fra nå av!" (Austen, Stolthet og fordom, c. 1972, 154).

53 "gjorde hun ikke skam på den verdighet som giftermålet hadde gitt henne" (Austen, Stolthet og fordom, 2003, 357).

54 "kom hun alltid til å holde vedlike det dårlige ryktet hun hadde fått i forbindelse med inngåelsen av ekteskapet" (Austen, Stolthet og fordom, 1947, 310). 
spokeswoman, Mrs Bennet. Hearing of Miss de Bourgh's future inheritance, she impulsively exclaims: "Ah! ... then she is better off than many girls" (67). The last word is certainly not unnecessary, but utterly significant. Alfsen, unfortunately, loses it in her translation: "then she is luckier than many others". The whole point, however, is Mrs Bennet's preoccupation with the economic dependence of girls, her own in particular. Knutsen's version carries another sense altogether: "that girl can certainly turn up her nose". The Hauges have succeeded in rendering the original meaning, and Harbitz is quite close, while the sentence has disappeared from the 1974 version. ${ }^{56}$

Similarly, if losing Mrs Bennet's often repeated complaints about "the entail" on their home, the focus on this issue in the novel is reduced, even if Mrs Bennet herself is ironized while doing so: "Well, if they can be easy with an estate that is not lawfully their own, so much the better. I should be ashamed of having one that was only entailed on me" (228). By taking out the words "lawfully" and "only entailed", the absurdity of her statement is softened, and the reminder of the law and the entail is gone. ${ }^{57}$

When translating a novel called Pride and Prejudice, we would perhaps expect a translator to be alert to these two concepts. Still, even these may be lost or confused, as when Knutsen translates "all her former prejudices had been removed" (368) as "had cleared up a lot of misunderstandings". ${ }^{58}$ In the concluding parts of a novel about prejudice, the main idea is lost in this rendering. ${ }^{59}$

A literary masterpiece, like a painted one, is full of shades and nuances, intricate details of words and meaning that together make up the reader's perception of characters and events. Reproducing, or more appropriately, recreating this in translation demands great presence of mind, and great skills of language. At their best, translations become new works of art in their own right, and as such are creative works, and by no means mere reproductions.

$5^{6}$ "Da er hun heldigere enn mange andre" (Austen, Stolthet og fordom, 2003, 68); "den jentungen kan nok sette nesen i været” (Austen, Stolthet og fordom, 1947, 66; Austen, Stolthet og fordom, c. 1972, 62; Austen, Elizabeth og hennes søstre, 1930, 54).

"Nå, hvis de kan gå og glede seg over en eiendom, som visselig ikke er deres egen, så gjerne for meg. Jeg ville skammet meg fryktelig" (Austen, Stolthet og fordom, 1947, 199). The Hauges have translated the first, but not the second (Austen, Stolthet og fordom, c. 1972, 185). Alfsen has kept both, but chosen a debatable and obscure word for entail; see Chapter 8 below (Austen, Stolthet og fordom, 2003, 216). Harbitz and the 1974 translator both delete it here, the latter in spite of giving a good translation of the concept when it first comes up in I, 13 .

58 "hadde ryddet av veien en mengde misforståelser" (Austen, Stolthet og fordom, 1947, 318).

59 The other translators have kept the word "prejudices" in this place, except for the 1974 version where it has disappeared in an abbreviated passage. 
It is not without reason that so many great authors through the centuries have also done translations, for instance Elizabeth Barrett Browning, George Eliot and Virginia Woolf. 60 They have obviously perceived it as a worthwhile enterprise for a proficient writer, as well as a much-needed channel of access to valuable texts by foreign colleagues of all periods. They demonstrate the perceived value of master pens also when employed for translation, and the recognition that translation is a demanding enterprise.

6o See discussion of the role of translation in for instance modernism in Wittman, "Literary narrative prose and translation studies", 2013, 442. 


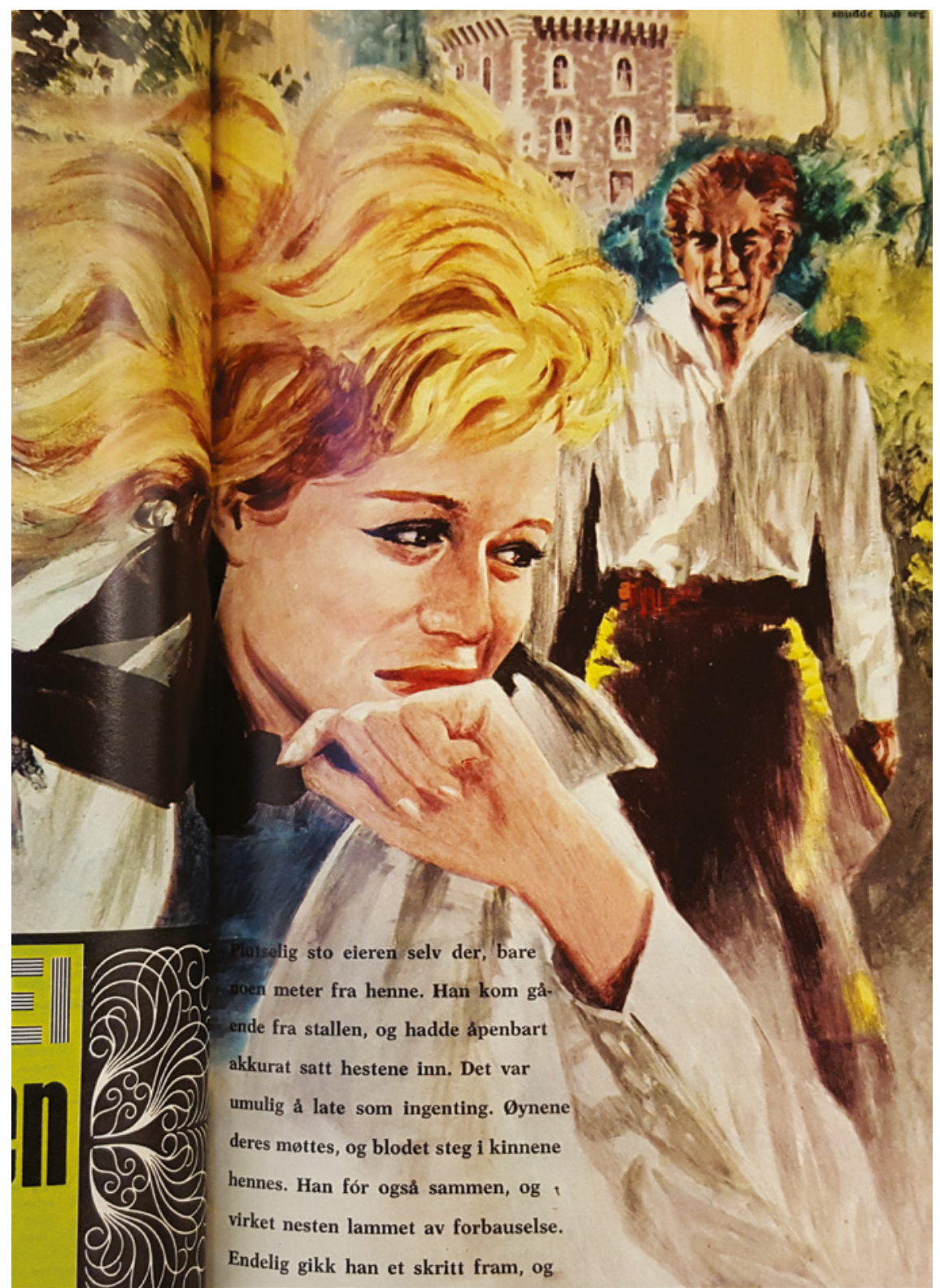

FIGURE 6 A 1974 version of Elizabeth and Darcy's surprise meeting at Pemberley for the Familien serial (illustrations by "Dick"). 


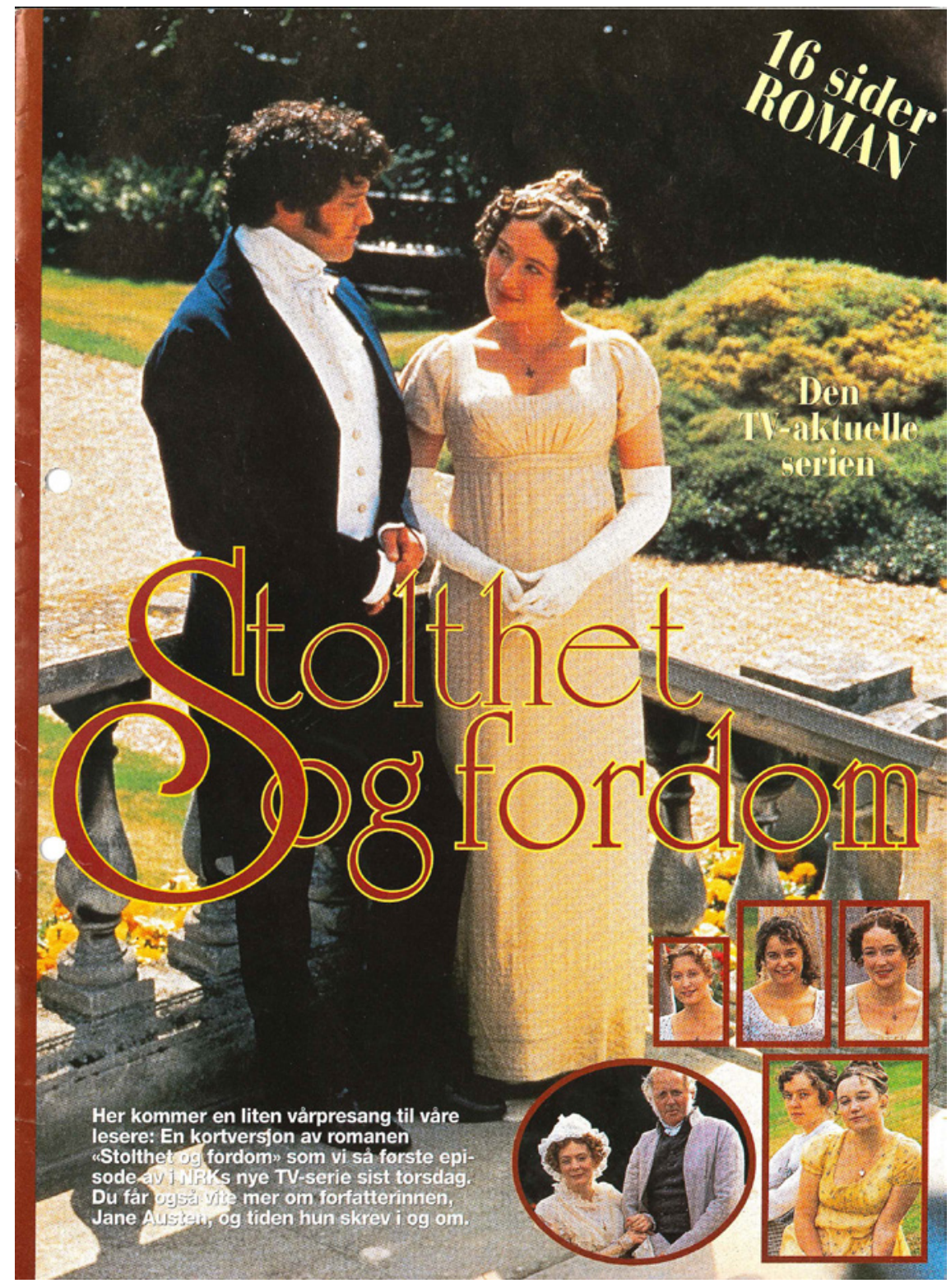

FIGURE 7 When the BBC Pride and Prejudice miniseries was aired in Norway in the spring of 1996, the magazine Familien offered their readers a special supplement with extracts from the novel. 